\title{
Adipsic Hypernatremia with Neurologic Manifestations in a Patient with Severe COVID-19 Pneumonia: A Case Report
}

Mohammad Kasim ${ }^{1}$, Gustav Strandvic ${ }^{1}$, Ismail Mahmood ${ }^{1}$, Muayad Ahmad ${ }^{2}$, and Abdulqadir Nashwan ${ }^{1}$

${ }^{1}$ Hamad Medical Corporation

${ }^{2}$ Hamad Medical Corp

December 2, 2021

\begin{abstract}
This report describes a case of a 50-year-old man with hypertension who was admitted with a history of fever, chills, and shortness of breath and tested positive for COVID-19. Shortly after resolving his ARDS, he developed an adipsic hypernatremia with associated confusion, lethargy, and weakness.
\end{abstract}

\section{Hosted file}

Hyp_Case_v0.0.docx available at https://authorea.com/users/449200/articles/547777adipsic-hypernatremia-with-neurologic-manifestations-in-a-patient-with-severe-covid19-pneumonia-a-case-report

\section{Hosted file}

Figure 1A.docx available at https://authorea.com/users/449200/articles/547777-adipsichypernatremia-with-neurologic-manifestations-in-a-patient-with-severe-covid-19pneumonia-a-case-report

\section{Hosted file}

Figure 1B.docx available at https://authorea.com/users/449200/articles/547777-adipsichypernatremia-with-neurologic-manifestations-in-a-patient-with-severe-covid-19pneumonia-a-case-report

\section{Hosted file}

Figure 2.docx available at https://authorea.com/users/449200/articles/547777-adipsichypernatremia-with-neurologic-manifestations-in-a-patient-with-severe-covid-19pneumonia-a-case-report 